OPEN ACCESS

Edited by:

Iris Eke,

Stanford University, United States

Reviewed by:

Saravanan Andalur Nandagopal,

Stanford University, United States

Defne Bayik,

Cleveland Clinic, United States Liang Wang,

University of Texas MD Anderson

Cancer Center, United States

*Correspondence:

Claire Vanpouille-Box clv2002@med.cornell.edu

Specialty section:

This article was submitted to Cancer Molecular Targets and Therapeutics,

a section of the journal

Frontiers in Oncology

Received: 22 February 2021 Accepted: 13 April 2021

Published: 20 May 2021

Citation:

De Martino M, Padilla $O$,

Daviaud C, Wu C-C, Gartrell RD and

Vanpouille-Box C (2021) Exploiting

Radiation Therapy to Restore Immune

Reactivity of Glioblastoma.

Front. Oncol. 11:671044.

doi: 10.3389/fonc.2021.671044

\section{Exploiting Radiation Therapy to Restore Immune Reactivity of Glioblastoma}

\author{
Mara De Martino ${ }^{1}$, Oscar Padilla ${ }^{2}$, Camille Daviaud ${ }^{1}$, Cheng-Chia Wu ${ }^{2,3}$, Robyn D. Gartrell ${ }^{4}$ \\ and Claire Vanpouille-Box ${ }^{1,5 *}$ \\ ${ }^{1}$ Department of Radiation Oncology, Weill Cornell Medicine, New York, NY, United States, ${ }^{2}$ Department of Radiation Oncology, \\ Columbia University Irving Medical Center, New York, NY, United States, ${ }^{3}$ Herbert Irving Comprehensive Cancer Center, New York, \\ NY, United States, ${ }^{4}$ Department of Pediatrics, Pediatric Hematology/Oncology/SCT, Columbia University Irving Medical Center, \\ New York, NY, United States, ${ }^{5}$ Sandra and Edward Meyer Cancer Center, New York, NY, United States
}

Glioblastoma (GBM) is among the most aggressive of brain tumors and confers a dismal prognosis despite advances in surgical technique, radiation delivery methods, chemotherapy, and tumor-treating fields. While immunotherapy (IT) has improved the care of several adult cancers with previously dismal prognoses, monotherapy with IT in GBM has shown minimal response in first recurrence. Recent discoveries in lymphatics and evaluation of blood brain barrier offer insight to improve the use of ITs and determine the best combinations of therapies, including radiation. We highlight important features of the tumor immune microenvironment in GBM and potential for combining radiation and immunotherapy to improve prognosis in this devastating disease.

Keywords: glioblastoma, radiotherapy, immunotherapy, antigenicity, adjuvanticity, immunosuppression

\section{INTRODUCTION}

Glioblastoma (GBM), a high-grade glial tumor, is the most frequent malignant primary brain tumor in adults (1). GBM prognosis remains dismal with a low 5-year survival rate of only $5.6 \%$ (1) and a median overall survival (OS) of approximately 18 months (2).

Immunotherapies (ITs) have long been overlooked for the treatment of central nervous system (CNS) malignancies presumably due to the long-held view of the brain as an immune-privileged compartment. However, the discovery of a dural lymphatic system $(3,4)$, the ability of some CNStissue resident cells to present antigen (5-9) and the functional characterization of the dural sinuses as an immune interface of the CNS (10) have introduced a paradigm shift whereby the brain possesses an immune-distinct tumor microenvironment (TME) that is still accessible for ITs (1113). Since then, efforts have spurred in clinic to evaluate the efficacy of ITs in GBM (13), but the paucity of pre-existing $\mathrm{T}$ cells at diagnosis prevented the reactivation of anti-tumor immune responses (14-16). Notably, monotherapy with ITs have shown poor response rate in first GBM recurrence (17). In evaluation of responders to anti-PD1 monotherapy at first recurrence, patients are more likely to be Phosphatase and TENsin homolog (PTEN) wild type and have increased immune infiltration post anti-PD1 monotherapy compared to non-responders who are PTEN mutant and have low immune infiltrate both before and after IT (18). Consequently, it is critical to develop IT-based combinatorial approaches that both recruit and activate tumor-infiltrating lymphocytes (TILs). 
Radiation therapy (RT) increases antigenicity and adjuvanticity of malignant cells (19), thus suggesting that RT could be used to coax T cells into GBM. Supporting this notion, several groups have reported synergism between RT and IT in preclinical models of GBM which have motivated the assessment of RT-based combinatorial approaches in Clinic (Table 1).

Here will we discuss the unique immune system of the central nervous system (CNS), the immunosuppressive TME of GBM and how RT can restore the sensitivity of GBM to modern IT by modulating systemic and local anti-tumor immunity.

\section{THE UNIQUE IMMUNE SYSTEM OF THE CENTRAL NERVOUS SYSTEM}

The traditional dogma of the brain as an immune-privileged organ was initiated by pioneer work from Murphy in the 1920s, demonstrating successful growth of mouse sarcoma after their implantation into the brain while rejection of these tumors was observed when transplanted in the periphery (20). Later on, these findings were confirmed with seminal work from Medawar, in the 1940s, which similarly demonstrate a high propensity of tumor engraftment in the brain parenchyma as opposed to tumor transplant in peripheral organs (21). Of notice, when first transplanted in peripheral organs before their implantation into the brain, these tumors were successfully rejected, thus suggesting that the activation of the immune system in the periphery can generate tumor rejection into the brain (21). Consequently, the fact that brains were unable to elicit antitumor immune responses by itself led to the concept of the immune privilege of the CNS.

Since then, studies have revealed that the immune privilege status of the CNS is overstated. Notably, the description of the afferent mechanism for CNS engagement in regional lymphatic (22-24) together with the discovery of the glymphatic (gliallymphatic) system that links the parenchyma and the interstitium to the cerebrospinal fluid (CSF) spaces, started to challenge the concept of the brain as immunologically silenced.

Another breakthrough in the field of brain immunology was the identification of a functional meningeal lymphatic network that enables the drainage of immune cells, macromolecules and fluids from the CNS to the deep cervical lymph nodes (dcLN) (4, 25). This dural lymphatic system provides a physical connection for CSF-derived antigens to gain access to dcLN for priming and activation of $\mathrm{T}$ cells. Consequently, meningeal lymphatic vessels are critical regulators of drainage and immune surveillance, a notion that has been demonstrated in the context of GBM (26, 27). More recently, the dural sinuses were identified as a neuroimmune hub where circulating $\mathrm{T}$ cells can assess the brain and CSF-derived antigens to enable immune surveillance (10).

Given the complex lymphatic circuitry and the unique sites of neuro-interface of the CNS, the brain can no longer be perceived as an immune-privileged organ, but rather as an immunedistinct and highly immunosuppressive environment.

This concept is reinforced by the ongoing challenge of the efferent arm of CNS immunity. Indeed, the blood brain barrier
(BBB), a structure composed of capillary tight junctions and astrocyte cell projections (aka astrocytic feet or "glia limitans") $(28,29)$, is thought to serve as a filter of the transit of molecules and immune cells between the brain and the systemic circulation. Some strategies to overcome the BBB have been explored, including the usage of nanoparticles, convection enhanced delivery, and non-invasive focused ultrasound and have achieved promising results in preclinical models (30-34). However, the recent demonstration of $\mathrm{T}$ cells infiltration and immune surveillance of the brain challenge the long-held view of $\mathrm{BBB}$ as an hermetic barrier to immune cell trafficking and suggest that the CNS is accessible to immune cells (35-37).

Aside distinct afferent and efferent circuits of CNS immunity, tissue-resident myeloid cells are another unique feature of brain immunity (38). This population is mainly composed of microglia (or tissue-resident macrophages) that originate from the yolk sac and migrate into the brain during embryonic development (39). The function of microglia is to assess the brain parenchyma and to maintain immunological homeostasis by responding to signals consistent with tissue damage, inflammation, or the presence of pathogens $(40,41)$. Such activation of the microglia leads to an increase capacity of antigen presenting functions as well as its phagocytic properties, suggesting that microglia serves as the resident antigen-presenting cells of the CNS $(5,9)$.

Thus, the unique features of the brain from its drainage to its tissue resident microglial cells (Figure 1) suggest that immune responses in the CNS are possible. However, the immune singularity of the brain calls for a better understanding of CNS immunity to optimally generate anti-tumor immunity against brain malignancies.

\section{THE IMMUNE SUPPRESSIVE MICROENVIRONMENT OF GLIOBLASTOMA}

A major obstacle to anti-tumor immune responses against GBM is its highly immunosuppressive TME (Figure 1).

Among key contributors to GBM immunosuppression, tumorassociated macrophages cells (TAMs) account for $30 \%$ to $50 \%$ of the tumor mass $(42,43)$. TAMs are usually pro-tumorigenic, and their accumulation correlate with tumor grade and poor prognosis (44-46). The recruitment and function of TAMs is modulated by GBM-secreted factors, such as the chemo-attractants stromal cellderived factor 1 (SDF1) $(47,48), \mathrm{C}-\mathrm{C}$ motif chemokine ligand 2 (CCL2) $(49,50)$ and the colony-stimulation factor 1 (CSF1) (51). TAMs promote immunosuppression by the production of arginase, transforming growth factor-beta (TGF $\beta$ ), interleukin (IL)-10 and IL-6, among others which collectively inhibit both the innate and adaptive immune systems with suppression of NK activity and $\mathrm{T}$ cell activation and proliferation (52-55).

Another mechanism responsible for immunosuppression and ultimately the lack of response of IT strategies in GBM patient is the low representation of $\mathrm{T}$ cells in the tumor. Studies have demonstrated that T cells influx in GBM is offset as a result of (1) reduced $\mathrm{T}$ cells production subsequent to thymic involution (56), 
TABLE 1 | Combination of immunotherapy with radiation therapy in clinical development for glioblastoma.

\begin{tabular}{|c|c|c|c|c|c|c|c|}
\hline Target & Agent & $\begin{array}{c}\text { New or } \\
\text { Recurrent }\end{array}$ & Phase & $\begin{array}{l}\text { Clinical Trial } \\
\text { ID }\end{array}$ & $\begin{array}{l}\text { Radiation } \\
\text { regimen }\end{array}$ & Status & Notes \\
\hline PD-1 & Nivolumab & $\begin{array}{l}\text { Newly } \\
\text { diagnosed }\end{array}$ & III & NCT02617589 & $\begin{array}{c}\text { Standard } \\
\text { fractionation }\end{array}$ & $\begin{array}{l}\text { Active, not } \\
\text { recruiting }\end{array}$ & $\begin{array}{c}\text { Unmethylated MGMT; comparison anti-PD-1 } \\
\text { versus TMZ each in combination with RT }\end{array}$ \\
\hline PD-1 & Nivolumab & $\begin{array}{l}\text { Newly } \\
\text { diagnosed }\end{array}$ & III & NCT02667587 & $\begin{array}{l}\text { Standard } \\
\text { fractionation }\end{array}$ & $\begin{array}{l}\text { Active, not } \\
\text { recruiting }\end{array}$ & $\begin{array}{l}\text { Methylated MGMT; TMZ plus RT combined with } \\
\text { anti-PD-1 }\end{array}$ \\
\hline PD-1 & Nivolumab & $\begin{array}{c}\text { Newly } \\
\text { diagnosed }\end{array}$ & 1 & NCT03576612 & $\begin{array}{c}\text { Standard } \\
\text { fractionation }\end{array}$ & Recruiting & Neoadjuvant onclolytic adenovirus (GMCl) + TMZ \\
\hline PD-1 & Nivolumab & Recurrent & $\|$ & NCT03743662 & Hypofractionated & Recruiting & $\begin{array}{c}\text { Re-irradiation }(6 \text { Gy } \times \text { 5) +/- anti-PD-1 +/- } \\
\text { Bevacizumab }\end{array}$ \\
\hline PD-1 & Nivolumab & $\begin{array}{c}\text { Newly } \\
\text { diagnosed }\end{array}$ & $\|$ & NCT04195139 & $\begin{array}{l}\text { Standard } \\
\text { fractionation }\end{array}$ & Recruiting & $\begin{array}{c}\text { Elderly patients; comparison RT+anti-PD-1 + } \\
\text { TMZ versus standard treatment }(R T+T M Z)\end{array}$ \\
\hline PD-1 & Pembrolizumab & $\begin{array}{l}\text { Newly } \\
\text { diagnosed }\end{array}$ & $\|$ & NCT03018288 & $\begin{array}{l}\text { Standard } \\
\text { fractionation }\end{array}$ & Recruiting & TMZ +/- heat shock protein (HSPPC-96) \\
\hline PD-1 & Pembrolizumab & $\begin{array}{l}\text { Newly } \\
\text { diagnosed }\end{array}$ & $\|$ & NCT03197506 & $\begin{array}{c}\text { Standard } \\
\text { fractionation }\end{array}$ & Recruiting & Standard therapy (RT+TMZ) +/- anti-PD-1 \\
\hline PD-1 & Pembrolizumab & Recurrent & I & NCT02313272 & $\begin{array}{l}\text { Standard } \\
\text { fractionation }\end{array}$ & $\begin{array}{l}\text { Active, not } \\
\text { recruiting }\end{array}$ & Bevacizumab and RT (6Gy x 5) +/- anti-PD-1 \\
\hline PD-1 & Pembrolizumab & $\begin{array}{l}\text { Newly } \\
\text { diagnosed }\end{array}$ & $\|$ & NCT03899857 & $\begin{array}{l}\text { Standard } \\
\text { fractionation }\end{array}$ & Recruiting & standard treatment $(\mathrm{RT}+\mathrm{TMZ})+$ anti-PD-1 \\
\hline PD-1 & Pembrolizumab & $\begin{array}{c}\text { Newly } \\
\text { diagnosed }\end{array}$ & 1 & NCT02287428 & $\begin{array}{l}\text { Standard } \\
\text { fractionation }\end{array}$ & Recruiting & $\begin{array}{c}\text { Unmethylated MGMT; RT+anti-PD-1+NeoAntigen } \\
\text { Vaccine }\end{array}$ \\
\hline PD-1 & Pembrolizumab & $\begin{array}{l}\text { Newly } \\
\text { diagnosed }\end{array}$ & 1 & NCT03426891 & $\begin{array}{l}\text { Standard } \\
\text { fractionation }\end{array}$ & Recruiting & $\begin{array}{l}\text { Standard therapy (RT+TMZ) +/- HDAC inhibitor } \\
\text { (Vorinostat) +/- anti-PD-1 }\end{array}$ \\
\hline PD-1 & Pembrolizumab & Recurrent & $\|$ & NCT03661723 & Hypofractionated & Recruiting & $\begin{array}{c}\text { Re-irradiation (7Gy x 5) per week for } 2 \text { weeks }+/- \\
\text { Bevacizumab }\end{array}$ \\
\hline PD-1 and CTLA-4 & $\begin{array}{l}\text { Nivolumab and } \\
\text { Ipilimumab }\end{array}$ & $\begin{array}{l}\text { Newly } \\
\text { diagnosed }\end{array}$ & $\|$ & NCT03367715 & Hypofractionated & Recruiting & $\begin{array}{c}\text { Unmethylated MGMT; RT (6Gy x 5) + anti-PD-1 + } \\
\text { anti-CTLA4 }\end{array}$ \\
\hline PD-1 and CTLA-4 & $\begin{array}{l}\text { Nivolumab and } \\
\text { Ipilimumab }\end{array}$ & $\begin{array}{l}\text { Newly } \\
\text { diagnosed }\end{array}$ & $\|/\| \|$ & NCT04396860 & $\begin{array}{l}\text { Standard } \\
\text { fractionation }\end{array}$ & Recruiting & $\begin{array}{c}\text { Unmethylated MGMT; comparison standard } \\
\text { treatment }(R T+T M Z) \text { versus } R T+\text { anti-PD-1+anti- } \\
\text { CTLA-4 }\end{array}$ \\
\hline PD-1 and IDO & $\begin{array}{l}\text { Nivolumab and } \\
\text { BMS-986205 }\end{array}$ & $\begin{array}{c}\text { Newly } \\
\text { diagnosed }\end{array}$ & 1 & NCT04047706 & $\begin{array}{c}\text { Standard } \\
\text { fractionation }\end{array}$ & Recruiting & $\begin{array}{c}\text { Standard treatment }(\mathrm{RT}+\mathrm{TMZ})+/- \text { anti-PD-1 +/- } \\
\text { IDO inhibitor }\end{array}$ \\
\hline PD-L1 & Durvalumab & $\begin{array}{l}\text { Newly } \\
\text { diagnosed and } \\
\text { recurrent }\end{array}$ & $\|$ & NCT02336165 & $\begin{array}{c}\text { Standard } \\
\text { fractionation }\end{array}$ & $\begin{array}{l}\text { Active, not } \\
\text { recruiting }\end{array}$ & Bevacizumab \\
\hline PD-L1 & Durvalumab & Recurrent & $|/| \mid$ & NCT02866747 & Hypofractionated & Recruiting & RT (8Gy x 3) \\
\hline PD-L1 & Atezolizumab & $\begin{array}{c}\text { Newly } \\
\text { diagnosed }\end{array}$ & $|/| \mid$ & NCT03174197 & $\begin{array}{l}\text { Standard } \\
\text { fractionation }\end{array}$ & $\begin{array}{l}\text { Active, not } \\
\text { recruiting }\end{array}$ & Standard treatment $(\mathrm{RT}+\mathrm{TMZ})+/-$ anti-PD-L1 \\
\hline PD-L1 & Avelumab & $\begin{array}{c}\text { Newly } \\
\text { diagnosed }\end{array}$ & $\|$ & NCT02968940 & Hypofractionated & Completed & IDH mutant; RT (6Gy x 5) \\
\hline PD-L1 & Avelumab & $\begin{array}{l}\text { Newly } \\
\text { diagnosed }\end{array}$ & $\|$ & NCT03047473 & $\begin{array}{l}\text { Standard } \\
\text { fractionation }\end{array}$ & $\begin{array}{l}\text { Active, not } \\
\text { recruiting }\end{array}$ & Standard treatment $(\mathrm{RT}+\mathrm{TMZ})+/-$ anti-PD-L1 \\
\hline PD-L1 & Avelumab & Recurrent & $\|$ & NCT03291314 & $\begin{array}{l}\text { Standard } \\
\text { fractionation }\end{array}$ & Completed & $\begin{array}{c}\text { Standard treatment }(\mathrm{RT}+\mathrm{TMZ})+\text { anti-PD-L1 } \\
\text { tyrosine kinase inhibitor (axitinib) }\end{array}$ \\
\hline GM-CSF & Sargranostim & $\begin{array}{l}\text { Newly } \\
\text { diagnosed }\end{array}$ & $\|$ & NCT02663440 & Hypofractionated & Unknown & $\mathrm{RT}$ (regimen not specified) + TMZ + GM-CSF \\
\hline GM-CSF and poly I:C & $\begin{array}{l}\text { Sargranostim } \\
\text { and Hiltonol }\end{array}$ & Recurrent & । & NCT03392545 & Not specified & Recruiting & $\mathrm{RT}+\mathrm{GM}-\mathrm{CSF}$ and poly I:C \\
\hline $\begin{array}{l}\text { GM-CSF and } \\
\text { tetanus-diphtheria } \\
\text { toxoid (Td) }\end{array}$ & $\begin{array}{l}\text { GM-CSF and } \\
\text { Td }\end{array}$ & $\begin{array}{l}\text { Newly } \\
\text { diagnosed }\end{array}$ & $\|$ & NCT03927222 & $\begin{array}{c}\text { Standard } \\
\text { fractionation }\end{array}$ & Recruiting & $\begin{array}{l}\text { Unmethylated MGMT; Standard treatment } \\
\qquad(R T+T M Z)+T d+G M-C S F\end{array}$ \\
\hline TGF- $\beta$ & Galunisertib & $\begin{array}{c}\text { Newly } \\
\text { diagnosed }\end{array}$ & $|/| \mid$ & NCT01220271 & $\begin{array}{l}\text { Standard } \\
\text { fractionation }\end{array}$ & Completed & Standard treatment $(\mathrm{RT}+\mathrm{TMZ})+/-$ anti-TGF- $\beta$ \\
\hline IDO & Indoximod & $\begin{array}{l}\text { Newly } \\
\text { diagnosed }\end{array}$ & $|/| \mid$ & NCT02052648 & Hypofractionated & Completed & $\begin{array}{c}\mathrm{TMZ}+/ \text { - bevacizumab +/- IDO inhibitor +/- RT } \\
(5.5 \times 5 \text { Gy })\end{array}$ \\
\hline CXCR4 & Plexirafor & $\begin{array}{c}\text { Newly } \\
\text { diagnosed }\end{array}$ & $|/| \mid$ & NCT01977677 & $\begin{array}{c}\text { Standard } \\
\text { fractionation }\end{array}$ & Completed & $\begin{array}{c}\text { Standard treatment }(\mathrm{RT}+\mathrm{TMZ})+/-\mathrm{CXCR} 4 \\
\text { inhibitor }\end{array}$ \\
\hline CSF1R & Pexidartinib & $\begin{array}{l}\text { Newly } \\
\text { diagnosed }\end{array}$ & $|/| \mid$ & NCT01790503 & $\begin{array}{l}\text { Standard } \\
\text { fractionation }\end{array}$ & Completed & $\begin{array}{c}\text { Standard treatment }(\mathrm{RT}+\mathrm{TMZ})+/-\mathrm{CSF} 1 \mathrm{R} \\
\text { inhibitor }\end{array}$ \\
\hline IGF-1R & IGV-001 & $\begin{array}{c}\text { Newly } \\
\text { diagnosed }\end{array}$ & lib & NCT04485949 & $\begin{array}{c}\text { Standard } \\
\text { fractionation }\end{array}$ & $\begin{array}{l}\text { Not yet } \\
\text { recruiting }\end{array}$ & $\begin{array}{c}\text { Standard treatment }(\mathrm{RT}+\mathrm{TMZ})+/-\mathrm{IGV}-001 \text { cell } \\
\text { immunotherapy }\end{array}$ \\
\hline PD-L1 & Atezolizumab & Recurrent & $\|$ & NCT04729959 & Hypofractionated & $\begin{array}{l}\text { Not yet } \\
\text { recruiting }\end{array}$ & IDH1 wild type; PD-L1 inhibitor; tocilizumab; RT \\
\hline
\end{tabular}



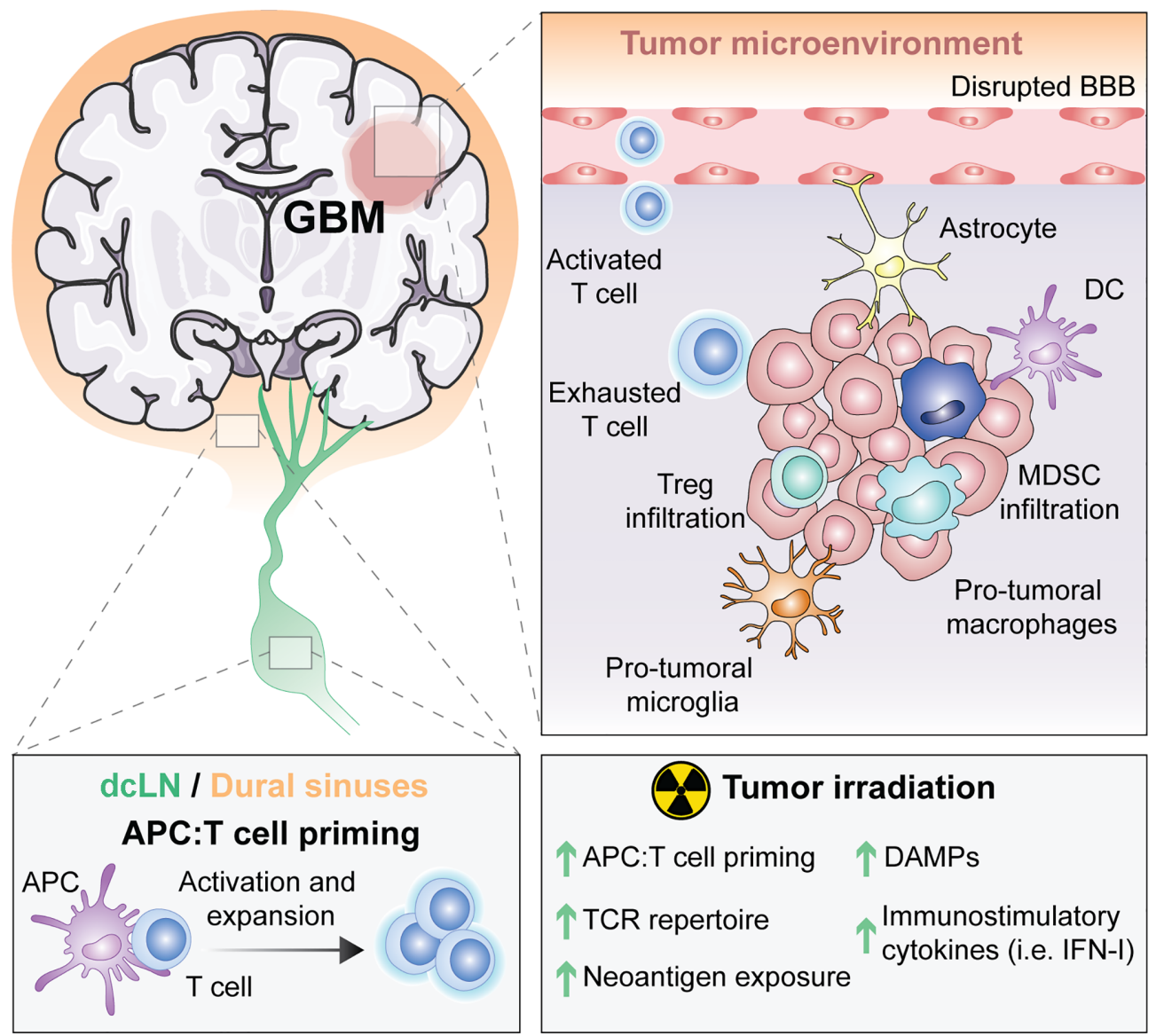

FIGURE 1 | The unique immune response in GBM and its modulation by RT. For many years, the central nervous system (CNS) was thought to be excluded from immune surveillance. However, it is now known that the CNS is not isolated from activated T cells and that CNS antigens can be presented locally or peripherally in the draining cervical lymph nodes or the dural sinuses. Diverse types of antigen presenting cells (APCs) exist within glioblastoma (GBM), including microglia, macrophages, astrocytes and classic APCs such as dendritic cells (DCs). APCs that have captured tumor antigens can present to naïve T cells, leading to their activation and expansion. Activated T cells migrate into the brain through a disrupted blood brain barrier (BBB), but once in the tumor microenvironment (TME) they differentiate into exhausted T cells. Within the TME, there are immunosuppressive regulatory T cells (Tregs), myeloid derived suppressor cells (MDSC), reactive astrocytes and pro-tumoral macrophages and microglia. Radiotherapy (RT), the standard of care for GBM, induces the exposure of tumor neoantigens and increases the T cell receptor (TCR) repertoire. Moreover, tumor irradiation promotes the release of danger associated molecular patterns (DAMPs) and type I interferon (IFN-I), which stimulate APCs cross-priming of T cells. All of these suggest that RT can be used to overcome GBM immunosuppression to optimally prime anti-tumor immunity.

(2) increased expression of the programmed death ligand-1 (PDL1) (57), (3) loss of surface spingosine-1-phosphate receptor 1 (S1P1) in brain tumors to sequester T cells in the bone marrow (58) and (4) CD68+ microglia lose MHC-II (i.e. heterogeneity human leukocyte antigen (HLA)-DR isotype; HLA-DR) expression in a PTEN dependent fashion (18).

Despite these major obstacles, some $\mathrm{T}$ cells can successfully infiltrate intracranial tumors and have been shown post IT in patients who respond (18). However, infiltrating $\mathrm{T}$ cells are more likely to be dysfunctional and express markers of exhaustion like programmed cell death (PD-1), lymphocyte-activation gene 3 (LAG3) and T-cell immunoglobulin and mucin-domain containing-3 (TIM-3) (59-61). Importantly, a large proportion of $\mathrm{T}$ cells infiltrating GBM are regulatory $\mathrm{T}$ cells (Tregs) that coexpressed checkpoint inhibitors including cytotoxic T-lymphocyteassociated protein 4 (CTLA-4) and PD-1 (62). Treg is a subset of
CD4 $\mathrm{T}$ cells that express the transcription factor forkhead box protein3 (Foxp3) $(63,64)$. These cells suppress CD8 T cells activation by the secretion of immunosuppressive cytokines, namely TGF $\beta$ and IL-10 $(65,66)$. GBM attract Tregs from the periphery to the local TME by soluble factors, such as GBM-derived CCL22, CCL2, and TGF $\beta$, to promote immunosuppression (66-69).

Overall, these findings underscore that not only do intracranial tumors display high infiltration of immunosuppressive cells but they also secrete factors that limit T cell responses against GBM.

The Cancer Genome Atlas (TCGA) has identified four subtypes of GBM (i.e. proneural, neural, classical, and mesenchymal), based on mutations that drive proliferation and survival of GBM (70). Consequently, the genetic heterogeneity of GBM predicts for a great mutational load, one of the favorable biomarkers for successful IT. However, GBM are characterized 
by a relatively low mutational burden $(71,72)$, suggesting that GBM display limited somatic mutations for the $\mathrm{T}$ cells to target and ultimately lead to a restricted efficacy of IT when used as monotherapy.

Defects in the antigen presentation machinery, such as downregulation or loss of HLA class I, have also been reported in GBM patients (73). More specifically, microglia antigenpresenting cells $(9,74)$ present a downregulation of the major histocompatibility class I (MHC-I) due to immunosuppressive cytokines (e.g. TGF $\beta$ and IL-10) that emanate from the TME (75).

Therefore, low presence of antigens combined with defective presentation, represent an additional challenge to mount effective $\mathrm{T}$ cell responses against GBM.

Metabolic alterations of GBM is an emerging immune resistance mechanism (76). Notably, a recent study comparing the metabolic reprogramming of GBM patient samples with lowgrade astrocytoma identified that variations in tryptophan, arginine, prostaglandin, and adenosine pathways might be responsible for the accumulation of Tregs and pro-tumorigenic TAMs in GBM (77). Moreover, activation of the mammalian target of rapamycin (mTOR) pathway in microglia promoted tumor growth and immune evasion in murine GBM (78). Therefore, targeting metabolic liabilities of intracranial tumors represents a promising strategy to overcome immunosuppression.

\section{RADIOTHERAPY TO RESTORE THE SENSITIVITY OF GLIOBLASTOMA TO IMMUNOTHERAPY}

The complexity of brain immunity combined with the immunosuppression exerted by the TME in brain tumors call for innovative approaches to break immune tolerance of brain malignancy.

One appealing strategy is to exploit the immuno-stimulatory properties of RT to generate an in situ tumor vaccine and the subsequent recruitment of effector $\mathrm{T}$ cells into GBM; a vital component for the efficacy of modern IT (Figure 1).

RT has been acknowledged as a potent immune adjuvant over the past two decades with major preclinical data demonstrating that RT promotes tumor specific T cell responses $(79,80)$. However, the concept of RT as an immune response modifier (IRM) was initiated forty years ago by Stone who demonstrated that responses to RT were impaired in the absence of T cells (81). While these findings were ignored for a long time, the breakthrough of ITs restimulated interest in exploiting the immunogenic properties of RT to expand the fraction of cancer patients that can benefit from IT. Since then, studies from experimental models have provided mechanistic insight pertaining to the ability of RT to stimulate the immune system. Notably, two main processes were found essential (but not mutually exclusive) to convey immunogenicity of an irradiated tumor: (1) the engagement of an immunogenic cell death (ICD) (82-85) and (2) the induction of type I interferon (IFN-I) (8688). ICD is identified by the spatial and temporal occurrence of three damage-associated molecular pattern (DAMPs) molecules, namely the pre-apoptotic exposure of calreticulin (CRT) on the cell surface (89), the active secretion of ATP $(82,83,89-92)$ and the release of the non-histone nuclear protein High Mobolity Group Box 1 (HMGB1) (82).

Activation of IFN-I response is essential for T cell priming and is a consequence of the recognition of cytosolic double stranded (ds) DNA by the nucleic acid sensor (NAS) CGAS (i.e. cyclic GMP-AMP synthase) to engage stimulator of the interferon genes (STING) pathway in irradiated cells as well as in dendritic cells (DC) $(87,88,93-98)$. The source of cytosolic DNA is currently being debated with reports indicating that micronuclei formed by mitotic defects (99-101) and/or the autophagy-dependent release of mitochondrial dsDNA (86).

Nevertheless, RT-induced IFN-I response is not restricted to cytoplasmic dsDNA sensing. Notably, recent studies have demonstrated that cytoplasmic recognition of dsRNA by the retinoic acid inducible gene I (RIG-I)-like receptors (RLRs) led to IFN-I post RT $(102,103)$. Cytosolic dsRNA sensing involves three RLR sensors, namely RIG-I, melanoma differentiationassociated gene 5 (MDA5), and laboratory of physiology and genetics 2 (LGP2 or DExH-box helicase 58; DHX58) $(104,105)$. A recent preclinical study, reported that host LGP2 was essential for optimal anti-tumor control of irradiated murine colorectal tumors (103). Consequently, the activation of RT-induced IFN-I is the result of DNA recognition by the CGAS-STING pathway but is also subsequent to RNA sensing by the RLR family. Whether these mechanisms are initiated in irradiated GBM remains unknown, but current data suggests that activation CGAS-STING in myeloid cells is important for anti-tumor immunity against this tumor type $(106,107)$.

Other major immunogenic features of RT is to shape the T cell receptor (TCR) repertoire of TILs (108-112) and to expose immunogenic mutations to the immune system (113). A detailed discussion describing the mechanisms responsible for the increase of antigenicity in irradiated tumors can be found elsewhere (114).

While the capacity of RT to generate similar mechanisms in the brain remains to be investigated, evidence of MHC-I upregulation and increase of antigen presentation from brain irradiation was described (115). More importantly, it was reported that personalized neoantigen vaccine generates intratumoral $\mathrm{T}$ cell responses in GBM patients, suggesting that RT-induced immunogenic mutation exposure is a promising strategy to treat intracranial tumors (116).

The impact of the isocitrate dehydrogenase 1 (IDH1) mutation together with the methylation status of O6-methylguanine-DNA methyltransferase (MGMT) on RT-induced anti-tumor immunity against GBM is unclear. However, the fact that neoantigen derived from mutant IDH1 can promote anti-tumor CD4+ T-cells and antibody responses in glioma together with the ability of RT to expose neoantigens, suggest that IDH1 mutated GBM patients might better respond to the RT-IT combinations as opposed to patients with wild-type IDH1 tumors (117).

Altogether, mechanistic insights pertaining to the immunogenic role and function of ionizing radiation elevated 
the use of RT as a partner to IT in multiple cancer including GBM. Some RT-IT combination are already assessed in preclinical models of GBM as well as in clinic (Table 1). For instance, focal irradiation improved the survival of GBM-tumor bearing mice treated with anti-PD-1 $(118,119)$, anti-CTLA-4 + 4-1BB activation (120), dual TIM-3 and PD-1 blockade (121) and anti-GITR (glucocorticoid-induced TNFR family related gene) (122). Underscoring the potential of RT to promote GBM-targeted $\mathrm{T}$ cells responses, all of these studies reported an increase in $\mathrm{T}$ cell infiltration and some even documented long-lasting immune memory responses against GBM.

Importantly myeloid cells expressing the colony-stimulating factor-1 receptor (CSF-1R) (or TAM-CSF-1R+ cells) were recently found altered during the time-course of anti-GBM therapy. Notably, RT was described to promote recurrencespecific phenotypes in microglia and monocyte-derived macrophages (123). GBM tumor bearing mice treated with the combination of anti-CSF-1R with focal RT experienced increase in survival, thus indicating that CSF-1R targeting is a promising strategy for irradiated GBM (123).

Along similar lines, targeting PD-L1 expressing tumor associated myeloid cells in combination with dinaciclib, a cyclin-dependent kinase inhibitor, extended survival of mice bearing irradiated GBM tumors (124).

\section{CLINICAL TRANSLATION AND CHALLENGES}

A widespread interest of RT-based immuno-oncology combinations has spurred in Clinic due to the mounting evidence highlighting the role RT as an immune adjuvant. However, the clinic translation of experimental models turn out to be more challenging than anticipated due to several of host-responses to RT. Notably, mounting evidence highlight the critical aspect of the choice of radiation fractionation and regimen to elicit anti-tumor immunity. Consequently, the impact of RT planning and delivery must be considered including: absolute dose, dose-per-fraction, low dose spread, path of radiation delivery, and the effects of radiation cell kill. Radiation dose fractionation and dose per fraction has shown to differentially affect immune cells and the TME. For instance, radiation dose-dependent responses can be elicited on T-effector cells versus Tregs, macrophages, and TME regulation through TREX1-STING-IFN signaling (87, 125-128). The optimal radiation dose and regimen together with the best sequencing between IT and RT remains elusive $(19,129,130)$.

Nevertheless, ongoing clinical trials assessing the combination of IT with either standard fractionation or hypofractionation regimen in CNS diseases (Table 1) may provide some indication on the optimal radiation regimen and sequencing of IT to generate GBM-targeted anti-tumor immune responses.

Another major limitation to RT-induced anti-tumor immunity is the activation of latent TGF $\beta$ that stem for the TME. TGF $\beta$ activation by RT promotes immunosuppression (131) and therefore represents a major challenge for the translation of RTIT combinations. Nevertheless, cooperative effects of TGF $\beta$ blockade with focal RT has shown some promises in patients with metastatic breast cancer $(132,133)$, which underscore that blocking TGF $\beta$ in the context of RT might be required to elicit potent anti-tumor immunity.

There are many emerging ionizing radiation technologies that may further add to the immune modulatory effects including ultras-fast dose-rate radiotherapy (FLASH-RT) and particle therapy (proton and carbon ion therapy) (134). While preclinical studies hold great promises to generates anti-tumor immunity against FLASH-irradiated GBM (135), additional investigations are required to define the immunogenic properties of FLASH radiation, especially in the context of brain malignancies.

Overall, to achieve clinical translation for patient care, increase knowledge of the interplay between radiation responses of the host and immunosuppression must be investigated.

\section{CONCLUSION}

Although to date, the clinical trials assessing the efficacy of IT have been disappointing, the results from preclinical studies are very encouraging for the success of RT-IT combinations in treating GBM. Different strategies adapted from experimental models are currently being investigated to harness the immense potential of combining RT with IT (Table 1). As a scientific community, we strongly await the data from these ongoing clinical trials. Further efforts to understand the effect of RT in TME of GBM may uncover novel avenues to optimally combine RT with IT to generate an in situ vaccination against GBM. However, given the complexity of the brain immunity, together with the immunosuppression of GBM, it is likely that multiple targets will be required to eliminate irradiated GBM.

\section{AUTHOR CONTRIBUTIONS}

All authors (MD, OP, CD, C-CW, RG, and CV-B) contributed to article writing and editing. All authors contributed to the article and approved the submitted version.

\section{FUNDING}

OP is supported by National Cancer Institute (NCI) Stimulating Access to Research in Residency (StARR) Award, supplement to the Columbia Cancer Research Program for Resident Investigators (CAPRI, R38CA231577). C-CW is supported by the Gary and Yael Fegel Family Foundation, the Star and Storm Foundation, the Matheson Foundation (UR010590), and a Herbert Irving Cancer Center Cancer Center Support Grant (P30CA013696). RG is supported by Swim Across America and Hyundai Hope on Wheels Hope Scholar Award. CV-B is supported by a startup grant from the Department of Radiation Oncology at Weill Cornell Medicine and a Brain Cancer Research Investigator Grant from $\mathrm{B}^{\star}$ CURED. 


\section{REFERENCES}

1. Ostrom QT, Gittleman H, Truitt G, Boscia A, Kruchko C, Barnholtz-Sloan JS. CBTRUS Statistical Report: Primary Brain and Other Central Nervous System Tumors Diagnosed in the United States in 2011-2015. Neuro Oncol (2018) 20(suppl_4):iv1-iv86. doi: 10.1093/neuonc/noy131

2. Stupp R, Taillibert S, Kanner A, Read W, Steinberg D, Lhermitte B, et al. Effect of Tumor-Treating Fields Plus Maintenance Temozolomide vs Maintenance Temozolomide Alone on Survival in Patients With Glioblastoma: A Randomized Clinical Trial. JAMA (2017) 318(23):230616. doi: $10.1001 /$ jama.2017.18718

3. Louveau A, Harris TH, Kipnis J. Revisiting the Mechanisms of CNS Immune Privilege. Trends Immunol (2015) 36(10):569-77. doi: 10.1016/ j.it.2015.08.006

4. Louveau A, Smirnov I, Keyes TJ, Eccles JD, Rouhani SJ, Peske JD, et al. Structural and Functional Features of Central Nervous System Lymphatic Vessels. Nature (2015) 523(7560):337-41. doi: 10.1038/nature14432

5. Aloisi F, Ria F, Adorini L. Regulation of T-Cell Responses by CNS AntigenPresenting Cells: Different Roles for Microglia and Astrocytes. Immunol Today (2000) 21(3):141-7. doi: 10.1016/S0167-5699(99)01512-1

6. Beauvillain C, Donnou S, Jarry U, Scotet M, Gascan H, Delneste Y, et al. Neonatal and Adult Microglia Cross-Present Exogenous Antigens. Glia (2008) 56(1):69-77. doi: 10.1002/glia.20565

7. Becher B, Bechmann I, Greter M. Antigen Presentation in Autoimmunity and CNS Inflammation: How T Lymphocytes Recognize the Brain. J Mol Med (Berl) (2006) 84(7):532-43. doi: 10.1007/s00109-006-0065-1

8. Harris MG, Hulseberg P, Ling C, Karman J, Clarkson BD, Harding JS, et al. Immune Privilege of the CNS is Not the Consequence of Limited Antigen Sampling. Sci Rep (2014) 4:4422. doi: 10.1038/srep04422

9. Jarry U, Jeannin P, Pineau L, Donnou S, Delneste Y, Couez D. Efficiently Stimulated Adult Microglia Cross-Prime Naive CD8+ T Cells Injected in the Brain. Eur J Immunol (2013) 43(5):1173-84. doi: 10.1002/eji.201243040

10. Rustenhoven J, Drieu A, Mamuladze T, de Lima KA, Dykstra T, Wall M, et al. Functional Characterization of the Dural Sinuses as a Neuroimmune Interface. Cell (2021) 184(4):1000-31. doi: 10.1016/j.cell.2020.12.040

11. Preusser M, Lim M, Hafler DA, Reardon DA, Sampson JH. Prospects of Immune Checkpoint Modulators in the Treatment of Glioblastoma. Nat Rev Neurol (2015) 11(9):504-14. doi: 10.1038/nrneurol.2015.139

12. Wilcox JA, Ramakrishna R, Magge R. Immunotherapy in Glioblastoma. World Neurosurg (2018) 116:518-28. doi: 10.1016/j.wneu.2018.04.020

13. Lim M, Xia Y, Bettegowda C, Weller M. Current State of Immunotherapy for Glioblastoma. Nat Rev Clin Oncol (2018) 15(7):422-42. doi: 10.1038/s41571018-0003-5

14. Liu Z, Meng Q, Bartek JJr., Poiret T, Persson O, Rane L, et al. Tumor-Infiltrating Lymphocytes (Tils) From Patients With Glioma. Oncoimmunology (2017) 6(2): e1252894. doi: 10.1080/2162402X.2016.1252894

15. Li B, Severson E, Pignon JC, Zhao H, Li T, Novak J, et al. Comprehensive Analyses of Tumor Immunity: Implications for Cancer Immunotherapy. Genome Biol (2016) 17(1):174. doi: 10.1186/s13059-016-1028-7

16. Reardon DA, Wen PY, Wucherpfennig KW, Sampson JH. Immunomodulation for Glioblastoma. Curr Opin Neurol (2017) 30(3):361-9. doi: 10.1097/ WCO.0000000000000451

17. Omuro A, Vlahovic G, Lim M, Sahebjam S, Baehring J, Cloughesy T. Nivolumab With or Without Ipilimumab in Patients With Recurrent Glioblastoma: Results From Exploratory Phase I Cohorts of Checkmate 143. Neuro Oncol (2018) 20(5):674-86. doi: 10.1093/neuonc/nox208

18. Zhao J, Chen AX, Gartrell RD, Silverman AM, Aparicio L, Chu T, et al. Immune and Genomic Correlates of Response to Anti-PD-1 Immunotherapy in Glioblastoma. Nat Med (2019) 25(3):462-9. doi: 10.1038/s41591-019-0349-y

19. Rodriguez-Ruiz ME, Vanpouille-Box C, Melero I, Formenti SC, Demaria S. Immunological Mechanisms Responsible for Radiation-Induced Abscopal Effect. Trends Immunol (2018) 39(8):644-55. doi: 10.1016/j.it.2018.06.001

20. Murphy JB, Sturm E. Conditions Determining the Transplantability of Tissues in the Brain. J Exp Med (1923) 38(2):183-97. doi: 10.1084/ jem.38.2.183

21. Medawar PB. Immunity to Homologous Grafted Skin; the Fate of Skin Homografts Transplanted to the Brain, to Subcutaneous Tissue, and to the Anterior Chamber of the Eye. Br J Exp Pathol (1948) 29(1):58-69.
22. Bradbury MW, Westrop RJ. Factors Influencing Exit of Substances From Cerebrospinal Fluid Into Deep Cervical Lymph of the Rabbit. J Physiol (1983) 339:519-34. doi: 10.1113/jphysiol.1983.sp014731

23. Cserr HF, Knopf PM. Cervical Lymphatics, the Blood-Brain Barrier and the Immunoreactivity of the Brain: A New View. Immunol Today (1992) 13 (12):507-12. doi: 10.1016/0167-5699(92)90027-5

24. Goldmann J, Kwidzinski E, Brandt C, Mahlo J, Richter D, Bechmann I. T Cells Traffic From Brain to Cervical Lymph Nodes Via the Cribroid Plate and the Nasal Mucosa. J Leukoc Biol (2006) 80(4):797-801. doi: 10.1189/jlb.0306176

25. Aspelund A, Antila S, Proulx ST, Karlsen TV, Karaman S, Detmar M, et al. A Dural Lymphatic Vascular System That Drains Brain Interstitial Fluid and Macromolecules. J Exp Med (2015) 212(7):991-9. doi: 10.1084/jem.20142290

26. Song E, Mao T, Dong H, Boisserand LSB, Antila S, Bosenberg M, et al. VEGFC-Driven Lymphatic Drainage Enables Immunosurveillance of Brain Tumours. Nature (2020) 577(7792):689-94. doi: 10.1038/s41586-019-1912-x

27. Hu X, Deng Q, Ma L, Li Q, Chen Y, Liao Y, et al. Meningeal Lymphatic Vessels Regulate Brain Tumor Drainage and Immunity. Cell Res (2020) 30 (3):229-43. doi: 10.1038/s41422-020-0287-8

28. Tietz S, Engelhardt B. Brain Barriers: Crosstalk Between Complex Tight Junctions and Adherens Junctions. J Cell Biol (2015) 209(4):493-506. doi: $10.1083 /$ jcb.201412147

29. Huber JD, Egleton RD, Davis TP. Molecular Physiology and Pathophysiology of Tight Junctions in the Blood-Brain Barrier. Trends Neurosci (2001) 24(12):71925. doi: 10.1016/S0166-2236(00)02004-X

30. Taiarol L, Formicola B, Magro RD, Sesana S, Re F. An Update of NanoparticleBased Approaches for Glioblastoma Multiforme Immunotherapy. Nanomed (Lond) (2020) 15(19):1861-71. doi: 10.2217/nnm-2020-0132

31. Enriquez Perez J, Kopecky J, Visse E, Darabi A, Siesjo P. ConvectionEnhanced Delivery of Temozolomide and Whole Cell Tumor Immunizations in GL261 and KR158 Experimental Mouse Gliomas. BMC Cancer (2020) 20(1):7. doi: 10.1186/s12885-019-6502-7

32. Sheybani ND, Breza VR, Paul S, McCauley KS, Berr SS, Miller GW, et al. Immunopet-Informed Sequence for Focused Ultrasound-Targeted Mcd47 Blockade Controls Glioma. J Contr Rel (2021) 331:19-29. doi: 10.1016/ j.jconrel.2021.01.023

33. Yang FY, Wong TT, Teng MC, Liu RS, Lu M, Liang HF, et al. Focused Ultrasound and Interleukin-4 Receptor-Targeted Liposomal Doxorubicin for Enhanced Targeted Drug Delivery and Antitumor Effect in Glioblastoma Multiforme. J Contr Rel (2012) 160(3):652-8. doi: 10.1016/j.jconrel.2012.02.023

34. Vanpouille-Box C, Lacoeuille F, Belloche C, Lepareur N, Lemaire L, LeJeune JJ, et al. Tumor Eradication in Rat Glioma and Bypass of Immunosuppressive Barriers Using Internal Radiation With (188)Re-Lipid Nanocapsules. Biomaterials (2011) 32(28):6781-90. doi: 10.1016/j.biomaterials.2011.05.067

35. Schlager C, Korner H, Krueger M, Vidoli S, Haberl M, Mielke D, et al. Effector T-Cell Trafficking Between the Leptomeninges and the Cerebrospinal Fluid. Nature (2016) 530(7590):349-53. doi: 10.1038/ nature16939

36. Engelhardt B, Ransohoff RM. The Ins and Outs of T-Lymphocyte Trafficking to the CNS: Anatomical Sites and Molecular Mechanisms. Trends Immunol (2005) 26(9):485-95. doi: 10.1016/j.it.2005.07.004

37. Korn T, Kallies A. T Cell Responses in the Central Nervous System. Nat Rev Immunol (2017) 17(3):179-94. doi: 10.1038/nri.2016.144

38. Li X, Ranjith-Kumar CT, Brooks MT, Dharmaiah S, Herr AB, Kao C, et al. The RIG-I-Like Receptor LGP2 Recognizes the Termini of Double-Stranded RNA. J Biol Chem (2009) 284(20):13881-91. doi: 10.1074/jbc.M900818200

39. Ginhoux F, Greter M, Leboeuf M, Nandi S, See P, Gokhan S, et al. Fate Mapping Analysis Reveals That Adult Microglia Derive From Primitive Macrophages. Science (2010) 330(6005):841-5. doi: 10.1126/science.1194637

40. Nimmerjahn A, Kirchhoff F, Helmchen F. Resting Microglial Cells are Highly Dynamic Surveillants of Brain Parenchyma In Vivo. Science (2005) 308(5726):1314-8. doi: 10.1126/science.1110647

41. Davalos D, Grutzendler J, Yang G, Kim JV, Zuo Y, Jung S, et al. ATP Mediates Rapid Microglial Response to Local Brain Injury In Vivo. Nat Neurosci (2005) 8(6):752-8. doi: 10.1038/nn1472

42. Quail DF, Joyce JA. The Microenvironmental Landscape of Brain Tumors. Cancer Cell (2017) 31(3):326-41. doi: 10.1016/j.ccell.2017.02.009

43. Graeber MB, Scheithauer BW, Kreutzberg GW. Microglia in Brain Tumors. Glia (2002) 40(2):252-9. doi: 10.1002/glia.10147 
44. Komohara Y, Ohnishi K, Kuratsu J, Takeya M. Possible Involvement of the M2 Anti-Inflammatory Macrophage Phenotype in Growth of Human Gliomas. J Pathol (2008) 216(1):15-24. doi: 10.1002/path.2370

45. Hambardzumyan D, Gutmann DH, Kettenmann H. The Role of Microglia and Macrophages in Glioma Maintenance and Progression. Nat Neurosci (2016) 19(1):20-7. doi: 10.1038/nn.4185

46. Sorensen MD, Dahlrot RH, Boldt HB, Hansen S, Kristensen BW. TumourAssociated Microglia/Macrophages Predict Poor Prognosis in High-Grade Gliomas and Correlate With an Aggressive Tumour Subtype. Neuropathol Appl Neurobiol (2018) 44(2):185-206. doi: 10.1111/nan.12428

47. Wang SC, Hong JH, Hsueh C, Chiang CS. Tumor-Secreted SDF-1 Promotes Glioma Invasiveness and TAM Tropism Toward Hypoxia in a Murine Astrocytoma Model. Lab Invest (2012) 92(1):151-62. doi: 10.1038/ labinvest.2011.128

48. Kioi M, Vogel H, Schultz G, Hoffman RM, Harsh GR, Brown JM. Inhibition of Vasculogenesis, But Not Angiogenesis, Prevents the Recurrence of Glioblastoma After Irradiation in Mice. J Clin Invest (2010) 120(3):694705. doi: 10.1172/JCI40283

49. Platten M, Kretz A, Naumann U, Aulwurm S, Egashira K, Isenmann S, et al. Monocyte Chemoattractant Protein-1 Increases Microglial Infiltration and Aggressiveness of Gliomas. Ann Neurol (2003) 54(3):388-92. doi: 10.1002/ ana.10679

50. Takenaka MC, Gabriely G, Rothhammer V, Mascanfroni ID, Wheeler MA, Chao CC, et al. Control of Tumor-Associated Macrophages and T Cells in Glioblastoma Via AHR and CD39. Nat Neurosci (2019) 22(5):729-40. doi: 10.1038/s41593-019-0370-y

51. Pyonteck SM, Akkari L, Schuhmacher AJ, Bowman RL, Sevenich L, Quail DF, et al. CSF-1R Inhibition Alters Macrophage Polarization and Blocks Glioma Progression. Nat Med (2013) 19(10):1264-72. doi: 10.1038/nm.3337

52. Wang Q, He Z, Huang M, Liu T, Wang Y, Xu H, et al. Vascular Niche IL-6 Induces Alternative Macrophage Activation in Glioblastoma Through HIF2alpha. Nat Commun (2018) 9(1):559. doi: 10.1038/s41467-018-03050-0

53. Bloch O, Crane CA, Kaur R, Safaee M, Rutkowski MJ, Parsa AT. Gliomas Promote Immunosuppression Through Induction of B7-H1 Expression in Tumor-Associated Macrophages. Clin Cancer Res (2013) 19(12):3165-75. doi: 10.1158/1078-0432.CCR-12-3314

54. Lamano JB, Lamano JB, Li YD, DiDomenico JD, Choy W, Veliceasa D, et al. Glioblastoma-Derived IL6 Induces Immunosuppressive Peripheral Myeloid Cell PD-L1 and Promotes Tumor Growth. Clin Cancer Res (2019) 25 (12):3643-57. doi: 10.1158/1078-0432.CCR-18-2402

55. Gutmann DH, Kettenmann H. Microglia/Brain Macrophages as Central Drivers of Brain Tumor Pathobiology. Neuron (2019) 104(3):442-9. doi: 10.1016/j.neuron.2019.08.028

56. Andaloussi AE, Han Y, Lesniak MS. Progression of Intracranial Glioma Disrupts Thymic Homeostasis and Induces T-Cell Apoptosis In Vivo. Cancer Immunol Immunother (2008) 57(12):1807-16. doi: 10.1007/s00262-008-0508-3

57. Nduom EK, Wei J, Yaghi NK, Huang N, Kong LY, Gabrusiewicz K, et al. PDL1 Expression and Prognostic Impact in Glioblastoma. Neuro Oncol (2016) 18(2):195-205. doi: 10.1093/neuonc/nov172

58. Chongsathidkiet P, Jackson C, Koyama S, Loebel F, Cui X, Farber SH, et al. Sequestration of T Cells in Bone Marrow in the Setting of Glioblastoma and Other Intracranial Tumors. Nat Med (2018) 24(9):1459-68. doi: 10.1038/ s41591-018-0135-2

59. Mohme M, Schliffke S, Maire CL, Runger A, Glau L, Mende KC, et al. Immunophenotyping of Newly Diagnosed and Recurrent Glioblastoma Defines Distinct Immune Exhaustion Profiles in Peripheral and TumorInfiltrating Lymphocytes. Clin Cancer Res (2018) 24(17):4187-200. doi: 10.1158/1078-0432.CCR-17-2617

60. Woroniecka K, Chongsathidkiet P, Rhodin K, Kemeny H, Dechant C, Farber SH, et al. T-Cell Exhaustion Signatures Vary With Tumor Type and are Severe in Glioblastoma. Clin Cancer Res (2018) 24(17):4175-86. doi: 10.1158/10780432.CCR-17-1846

61. Park J, Kwon M, Kim KH, Kim TS, Hong SH, Kim CG, et al. Immune Checkpoint Inhibitor-Induced Reinvigoration of Tumor-Infiltrating CD8(+) T Cells is Determined by Their Differentiation Status in Glioblastoma. Clin Cancer Res (2019) 25(8):2549-59. doi: 10.1158/1078-0432.CCR-18-2564

62. Jacobs JF, Idema AJ, Bol KF, Nierkens S, Grauer OM, Wesseling P, et al. Regulatory T Cells and the PD-L1/PD-1 Pathway Mediate Immune
Suppression in Malignant Human Brain Tumors. Neuro Oncol (2009) 11 (4):394-402. doi: 10.1215/15228517-2008-104

63. El Andaloussi A, Lesniak MS. An Increase in CD4+CD25+FOXP3+ Regulatory $\mathrm{T}$ Cells in Tumor-Infiltrating Lymphocytes of Human Glioblastoma Multiforme. Neuro Oncol (2006) 8(3):234-43. doi: 10.1215/15228517-2006-006

64. Fecci PE, Mitchell DA, Whitesides JF, Xie W, Friedman AH, Archer GE, et al. Increased Regulatory T-Cell Fraction Amidst a Diminished CD4 Compartment Explains Cellular Immune Defects in Patients With Malignant Glioma. Cancer Res (2006) 66(6):3294-302. doi: 10.1158/00085472.CAN-05-3773

65. Iwata R, Hyoung Lee J, Hayashi M, Dianzani U, Ofune K, Maruyama M, et al. ICOSLG-Mediated Regulatory T-Cell Expansion and IL-10 Production Promote Progression of Glioblastoma. Neuro Oncol (2020) 22(3):333-44. doi: 10.1093/neuonc/noz204

66. Crane CA, Ahn BJ, Han SJ, Parsa AT. Soluble Factors Secreted by Glioblastoma Cell Lines Facilitate Recruitment, Survival, and Expansion of Regulatory T Cells: Implications for Immunotherapy. Neuro Oncol (2012) 14 (5):584-95. doi: 10.1093/neuonc/nos014

67. Chang AL, Miska J, Wainwright DA, Dey M, Rivetta CV, Yu D, et al. CCL2 Produced by the Glioma Microenvironment is Essential for the Recruitment of Regulatory T Cells and Myeloid-Derived Suppressor Cells. Cancer Res (2016) 76(19):5671-82. doi: 10.1158/0008-5472.CAN-16-0144

68. Jordan JT, Sun W, Hussain SF, DeAngulo G, Prabhu SS, Heimberger AB. Preferential Migration of Regulatory T Cells Mediated by Glioma-Secreted Chemokines can be Blocked With Chemotherapy. Cancer Immunol Immunother (2008) 57(1):123-31. doi: 10.1007/s00262-007-0336-x

69. Ueda R, Fujita M, Zhu X, Sasaki K, Kastenhuber ER, Kohanbash G, et al. Systemic Inhibition of Transforming Growth Factor-Beta in Glioma-Bearing Mice Improves the Therapeutic Efficacy of Glioma-Associated Antigen Peptide Vaccines. Clin Cancer Res (2009) 15(21):6551-9. doi: 10.1158/ 1078-0432.CCR-09-1067

70. Verhaak RG, Hoadley KA, Purdom E, Wang V, Qi Y, Wilkerson MD, et al. Integrated Genomic Analysis Identifies Clinically Relevant Subtypes of Glioblastoma Characterized by Abnormalities in PDGFRA, IDH1, EGFR, and NF1. Cancer Cell (2010) 17(1):98-110. doi: 10.1016/j.ccr.2009.12.020

71. Hodges TR, Ott M, Xiu J, Gatalica Z, Swensen J, Zhou S, et al. Mutational Burden, Immune Checkpoint Expression, and Mismatch Repair in Glioma: Implications for Immune Checkpoint Immunotherapy. Neuro Oncol (2017) 19(8):1047-57. doi: 10.1093/neuonc/nox026

72. Bouffet E, Larouche V, Campbell BB, Merico D, de Borja R, Aronson M, et al. Immune Checkpoint Inhibition for Hypermutant Glioblastoma Multiforme Resulting From Germline Biallelic Mismatch Repair Deficiency. J Clin Oncol (2016) 34(19):2206-11. doi: 10.1200/JCO.2016.66.6552

73. Facoetti A, Nano R, Zelini P, Morbini P, Benericetti E, Ceroni M, et al. Human Leukocyte Antigen and Antigen Processing Machinery Component Defects in Astrocytic Tumors. Clin Cancer Res (2005) 11(23):8304-11. doi: 10.1158/1078-0432.CCR-04-2588

74. Moseman EA, Blanchard AC, Nayak D, McGavern DB. T Cell Engagement of Cross-Presenting Microglia Protects the Brain From a Nasal Virus Infection. Sci Immunol (2020) 5(48):eabb1817. doi: 10.1126/sciimmunol.abb1817

75. Roy LO, Poirier MB, Fortin D. Transforming Growth Factor-Beta and its Implication in the Malignancy of Gliomas. Target Oncol (2015) 10(1):1-14. doi: 10.1007/s11523-014-0308-y

76. Bi J, Chowdhry S, Wu S, Zhang W, Masui K, Mischel PS. Altered Cellular Metabolism in Gliomas - an Emerging Landscape of Actionable CoDependency Targets. Nat Rev Cancer (2020) 20(1):57-70. doi: 10.1038/ s41568-019-0226-5

77. Kesarwani P, Prabhu A, Kant S, Chinnaiyan P. Metabolic Remodeling Contributes Towards an Immune-Suppressive Phenotype in Glioblastoma. Cancer Immunol Immunother (2019) 68(7):1107-20. doi: 10.1007/s00262019-02347-3

78. Dumas AA, Pomella N, Rosser G, Guglielmi L, Vinel C, Millner TO, et al. Microglia Promote Glioblastoma Via Mtor-Mediated Immunosuppression of the Tumour Microenvironment. EMBO J (2020) 39(15):e103790. doi: 10.15252/embj.2019103790

79. Vanpouille-Box C, Formenti SC, Demaria S. Toward Precision Radiotherapy for Use With Immune Checkpoint Blockers. Clin Cancer Res (2018) 24 (2):259-65. doi: 10.1158/1078-0432.CCR-16-0037 
80. Krombach J, Hennel R, Brix N, Orth M, Schoetz U, Ernst A, et al. Priming Anti-Tumor Immunity by Radiotherapy: Dying Tumor Cell-Derived Damps Trigger Endothelial Cell Activation and Recruitment of Myeloid Cells. Oncoimmunology (2019) 8(1):e1523097. doi: 10.1080/2162402X. 2018.1523097

81. Stone HB, Peters LJ, Milas L. Effect of Host Immune Capability on Radiocurability and Subsequent Transplantability of a Murine Fibrosarcoma. J Natl Cancer Inst (1979) 63(5):1229-35.

82. Apetoh L, Ghiringhelli F, Tesniere A, Obeid M, Ortiz C, Criollo A, et al. TollLike Receptor 4-Dependent Contribution of the Immune System to Anticancer Chemotherapy and Radiotherapy. Nat Med (2007) 13(9):10509. doi: $10.1038 / \mathrm{nm} 1622$

83. Golden EB, Frances D, Pellicciotta I, Demaria S, Helen Barcellos-Hoff M, Formenti SC. Radiation Fosters Dose-Dependent and ChemotherapyInduced Immunogenic Cell Death. Oncoimmunology (2014) 3:e28518. doi: 10.4161/onci.28518

84. Dadey DYA, Kapoor V, Khudanyan A, Thotala D, Hallahan DE. PERK Regulates Glioblastoma Sensitivity to ER Stress Although Promoting Radiation Resistance. Mol Cancer Res (2018) 16(10):1447-53. doi: 10.1158/1541-7786.MCR-18-0224

85. Kim W, Lee S, Seo D, Kim D, Kim K, Kim E, et al. Cellular Stress Responses in Radiotherapy. Cells (2019) 8(9):1105. doi: 10.3390/cells8091105

86. Yamazaki T, Kirchmair A, Sato A, Buque A, Rybstein M, Petroni G, et al. Mitochondrial DNA Drives Abscopal Responses to Radiation That are Inhibited by Autophagy. Nat Immunol (2020) 21(10):1160-71. doi: 10.1038/s41590-020-0751-0

87. Vanpouille-Box C, Alard A, Aryankalayil MJ, Sarfraz Y, Diamond JM, Schneider RJ, et al. DNA Exonuclease Trexl Regulates RadiotherapyInduced Tumour Immunogenicity. Nat Commun (2017) 8:15618. doi: $10.1038 /$ ncomms 15618

88. Deng L, Liang H, Xu M, Yang X, Burnette B, Arina A, et al. STINGDependent Cytosolic DNA Sensing Promotes Radiation-Induced Type I Interferon-Dependent Antitumor Immunity in Immunogenic Tumors. Immunity (2014) 41(5):843-52. doi: 10.1016/j.immuni.2014.10.019

89. Obeid M, Tesniere A, Ghiringhelli F, Fimia GM, Apetoh L, Perfettini JL, et al. Calreticulin Exposure Dictates the Immunogenicity of Cancer Cell Death. Nat Med (2007) 13(1):54-61. doi: 10.1038/nm1523

90. Galluzzi L, Vitale I, Aaronson SA, Abrams JM, Adam D, Agostinis P, et al. Molecular Mechanisms of Cell Death: Recommendations of the Nomenclature Committee on Cell Death 2018. Cell Death Differ (2018) 25 (3):486-541. doi: 10.1038/s41418-018-0102-y

91. Ghiringhelli F, Apetoh L, Tesniere A, Aymeric L, Ma Y, Ortiz C, et al. Activation of the NLRP3 Inflammasome in Dendritic Cells Induces IL1beta-Dependent Adaptive Immunity Against Tumors. Nat Med (2009) 15 (10):1170-8. doi: 10.1038/nm.2028

92. Kepp O, Senovilla L, Vitale I, Vacchelli E, Adjemian S, Agostinis P, et al. Consensus Guidelines for the Detection of Immunogenic Cell Death. Oncoimmunology (2014) 3(9):e955691. doi: 10.4161/21624011.2014.955691

93. Gao P, Ascano M, Wu Y, Barchet W, Gaffney BL, Zillinger T, et al. Cyclic [G $\left.\left(2^{\prime}, 5^{\prime}\right) \mathrm{Pa}\left(3^{\prime}, 5^{\prime}\right) \mathrm{P}\right]$ is the Metazoan Second Messenger Produced by DNAActivated Cyclic GMP-AMP Synthase. Cell (2013) 153(5):1094-107. doi: 10.1016/j.cell.2013.04.046

94. Mankan AK, Schmidt T, Chauhan D, Goldeck M, Honing K, Gaidt M, et al. Cytosolic RNA:DNA Hybrids Activate the Cgas-STING Axis. EMBO J (2014) 33(24):2937-46. doi: 10.15252/embj.201488726

95. Sun L, Wu J, Du F, Chen X, Chen ZJ. Cyclic GMP-AMP Synthase is a Cytosolic DNA Sensor That Activates the Type I Interferon Pathway. Science (2013) 339(6121):786-91. doi: 10.1126/science.1232458

96. Yoh SM, Schneider M, Seifried J, Soonthornvacharin S, Akleh RE, Olivieri $\mathrm{KC}$, et al. PQBP1 is a Proximal Sensor of the Cgas-Dependent Innate Response to HIV-1. Cell (2015) 161(6):1293-305. doi: 10.1016/j.cell. 2015.04.050

97. Ishikawa H, Barber GN. STING is an Endoplasmic Reticulum Adaptor That Facilitates Innate Immune Signalling. Nature (2008) 455(7213):674-8. doi: 10.1038/nature 07317

98. Ishikawa H, Ma Z, Barber GN. STING Regulates Intracellular DNAMediated, Type I Interferon-Dependent Innate Immunity. Nature (2009) 461(7265):788-92. doi: 10.1038/nature08476
99. Bakhoum SF, Ngo B, Laughney AM, Cavallo JA, Murphy CJ, Ly P, et al. Chromosomal Instability Drives Metastasis Through a Cytosolic DNA Response. Nature (2018) 553(7689):467-72. doi: 10.1038/nature25432

100. Harding SM, Benci JL, Irianto J, Discher DE, Minn AJ, Greenberg RA. Mitotic Progression Following DNA Damage Enables Pattern Recognition Within Micronuclei. Nature (2017) 548(7668):466-70. doi: 10.1038/ nature 23470

101. Mackenzie KJ, Carroll P, Martin CA, Murina O, Fluteau A, Simpson DJ, et al. Cgas Surveillance of Micronuclei Links Genome Instability to Innate Immunity. Nature (2017) 548(7668):461-5. doi: 10.1038/nature23449

102. Widau RC, Parekh AD, Ranck MC, Golden DW, Kumar KA, Sood RF, et al. RIG-I-Like Receptor LGP2 Protects Tumor Cells From Ionizing Radiation. Proc Natl Acad Sci USA (2014) 111(4):E484-91. doi: 10.1073/pnas.1323 253111

103. Zheng W, Ranoa DRE, Huang X, Hou Y, Yang K, Poli EC, et al. RIG-I-Like Receptor LGP2 is Required for Tumor Control by Radiotherapy. Cancer Res (2020) 80(24):5633-41. doi: 10.1158/0008-5472.CAN-20-2324

104. Reikine S, Nguyen JB, Modis Y. Pattern Recognition and Signaling Mechanisms of RIG-I and MDA5. Front Immunol (2014) 5:342. doi: 10.3389/fimmu.2014.00342

105. Chow KT, Gale MJr., Loo YM. RIG-I and Other RNA Sensors in Antiviral Immunity. Annu Rev Immunol (2018) 36:667-94. doi: 10.1146/annurevimmunol-042617-053309

106. Ohkuri T, Ghosh A, Kosaka A, Zhu J, Ikeura M, David M, et al. STING Contributes to Antiglioma Immunity Via Triggering Type I IFN Signals in the Tumor Microenvironment. Cancer Immunol Res (2014) 2(12):1199-208. doi: 10.1158/2326-6066.CIR-14-0099

107. von Roemeling CA, Wang Y, Qie Y, Yuan H, Zhao H, Liu X, et al. Therapeutic Modulation of Phagocytosis in Glioblastoma can Activate Both Innate and Adaptive Antitumour Immunity. Nat Commun (2020) 11 (1):1508. doi: 10.1038/s41467-020-15129-8

108. Formenti SC, Rudqvist NP, Golden E, Cooper B, Wennerberg E, Lhuillier C, et al. Radiotherapy Induces Responses of Lung Cancer to CTLA-4 Blockade. Nat Med (2018) 24(12):1845-51. doi: 10.1038/s41591-018-0232-2

109. Rudqvist NP, Pilones KA, Lhuillier C, Wennerberg E, Sidhom JW, Emerson RO, et al. Radiotherapy and CTLA-4 Blockade Shape the TCR Repertoire of Tumor-Infiltrating T Cells. Cancer Immunol Res (2018) 6(2):139-50. doi: 10.1158/2326-6066.CIR-17-0134

110. Chow J, Hoffend NC, Abrams SI, Schwaab T, Singh AK, Muhitch JB. Radiation Induces Dynamic Changes to the T Cell Repertoire in Renal Cell Carcinoma Patients. Proc Natl Acad Sci USA (2020) 117(38):23721-9. doi: 10.1073/pnas.2001933117

111. Wieland A, Kamphorst AO, Adsay NV, Masor JJ, Sarmiento J, Nasti TH, et al. T Cell Receptor Sequencing of Activated CD8 T Cells in the Blood Identifies Tumor-Infiltrating Clones That Expand After PD-1 Therapy and Radiation in a Melanoma Patient. Cancer Immunol Immunother (2018) 67 (11):1767-76. doi: 10.1007/s00262-018-2228-7

112. Cloughesy TF, Mochizuki AY, Orpilla JR, Hugo W, Lee AH, Davidson TB, et al. Neoadjuvant Anti-PD-1 Immunotherapy Promotes a Survival Benefit With Intratumoral and Systemic Immune Responses in Recurrent Glioblastoma. Nat Med (2019) 25(3):477-86. doi: 10.1038/s41591-0180337-7

113. Lhuillier C, Rudqvist NP, Yamazaki T, Zhang T, Charpentier M, Galluzzi L, et al. Radiotherapy-Exposed CD8+ and CD4+ Neoantigens Enhance Tumor Control. J Clin Invest (2021) 131(5):e138740. doi: 10.1172/JCI138740

114. Lhuillier C, Rudqvist NP, Elemento O, Formenti SC, Demaria S. Radiation Therapy and Anti-Tumor Immunity: Exposing Immunogenic Mutations to the Immune System. Genome Med (2019) 11(1):40. doi: 10.1186/s13073-0190653-7

115. Newcomb EW, Demaria S, Lukyanov Y, Shao Y, Schnee T, Kawashima N, et al. The Combination of Ionizing Radiation and Peripheral Vaccination Produces Long-Term Survival of Mice Bearing Established Invasive GL261 Gliomas. Clin Cancer Res (2006) 12(15):4730-7. doi: 10.1158/10780432.CCR-06-0593

116. Keskin DB, Anandappa AJ, Sun J, Tirosh I, Mathewson ND, Li S, et al. Neoantigen Vaccine Generates Intratumoral T Cell Responses in Phase Ib Glioblastoma Trial. Nature (2019) 565(7738):234-9. doi: 10.1038/s41586018-0792-9 
117. Schumacher T, Bunse L, Pusch S, Sahm F, Wiestler B, Quandt J, et al. A Vaccine Targeting Mutant IDH1 Induces Antitumour Immunity. Nature (2014) 512(7514):324-7. doi: 10.1038/nature13387

118. Zeng J, See AP, Phallen J, Jackson CM, Belcaid Z, Ruzevick J, et al. Anti-PD-1 Blockade and Stereotactic Radiation Produce Long-Term Survival in Mice With Intracranial Gliomas. Int J Radiat Oncol Biol Phys (2013) 86(2):343-9. doi: 10.1016/j.ijrobp.2012.12.025

119. Stessin AM, Clausi MG, Zhao Z, Lin H, Hou W, Jiang Z, et al. Repolarized Macrophages, Induced by Intermediate Stereotactic Dose Radiotherapy and Immune Checkpoint Blockade, Contribute to Long-Term Survival in Glioma-Bearing Mice. J Neurooncol (2020) 147(3):547-55. doi: 10.1007/ s11060-020-03459-y

120. Belcaid Z, Phallen JA, Zeng J, See AP, Mathios D, Gottschalk C. Focal Radiation Therapy Combined With 4-1BB Activation and CTLA-4 Blockade Yields Long-Term Survival and a Protective Antigen-Specific Memory Response in a Murine Glioma Model. PloS One (2014) 9(7):e101764. doi: 10.1371/journal.pone.0101764

121. Kim JE, Patel MA, Mangraviti A, Kim ES, Theodros D, Velarde E, et al. Combination Therapy With Anti-PD-1, Anti-TIM-3, and Focal Radiation Results in Regression of Murine Gliomas. Clin Cancer Res (2017) 23(1):12436. doi: 10.1158/1078-0432.CCR-15-1535

122. Patel MA, Kim JE, Theodros D, Tam A, Velarde E, Kochel CM, et al. Agonist Anti-GITR Monoclonal Antibody and Stereotactic Radiation Induce Immune-Mediated Survival Advantage in Murine Intracranial Glioma. J Immunother Cancer (2016) 4:28. doi: 10.1186/2051-1426-3-S2P194

123. Akkari L, Bowman RL, Tessier J, Klemm F, Handgraaf SM, de Groot M, et al. Dynamic Changes in Glioma Macrophage Populations After Radiotherapy Reveal CSF-1R Inhibition as a Strategy to Overcome Resistance. Sci Transl Med (2020) 12(552):eaaw7843. doi: 10.1126/scitranslmed.aaw7843

124. Zhang P, Miska J, Lee-Chang C, Rashidi A, Panek WK, An S, et al. Therapeutic Targeting of Tumor-Associated Myeloid Cells Synergizes With Radiation Therapy for Glioblastoma. Proc Natl Acad Sci USA (2019) 116:23714-23. doi: 10.1073/pnas.1906346116

125. Cao M, Cabrera R, Xu Y, Liu C, Nelson D. Different Radiosensitivity of CD4 (+)CD25(+) Regulatory T Cells and Effector T Cells to Low Dose Gamma Irradiation In Vitro. Int J Radiat Biol (2011) 87(1):71-80. doi: 10.3109/ 09553002.2010.518208

126. Kachikwu EL, Iwamoto KS, Liao YP, DeMarco JJ, Agazaryan N, Economou JS, et al. Radiation Enhances Regulatory T Cell Representation. Int J Radiat Oncol Biol Phys (2011) 81(4):1128-35. doi: 10.1016/j.ijrobp.2010.09.034

127. Klug F, Prakash H, Huber PE, Seibel T, Bender N, Halama N, et al. Low-Dose Irradiation Programs Macrophage Differentiation to an Inos(+)/M1
Phenotype That Orchestrates Effective T Cell Immunotherapy. Cancer Cell (2013) 24(5):589-602. doi: 10.1016/j.ccr.2013.09.014

128. Wang Y. Advances in Hypofractionated Irradiation-Induced Immunosuppression of Tumor Microenvironment. Front Immunol (2020) 11:612072. doi: 10.3389/ fimmu.2020.612072

129. Gunderson AJ, Young KH. Exploring Optimal Sequencing of Radiation and Immunotherapy Combinations. Adv Radiat Oncol (2018) 3(4):494-505. doi: 10.1016/j.adro.2018.07.005

130. De Martino M, Daviaud C, Vanpouille-Box C. Radiotherapy: An Immune Response Modifier for Immuno-Oncology. Semin Immunol (2021) p:101474. doi: 10.1016/j.smim.2021.101474

131. Vanpouille-Box C, Diamond JM, Pilones KA, Zavadil J, Babb JS, Formenti SC, et al. Tgfbeta is a Master Regulator of Radiation Therapy-Induced Antitumor Immunity. Cancer Res (2015) 75(11):2232-42. doi: 10.1158/ 0008-5472.CAN-14-3511

132. Formenti SC, Lee P, Adams S, Goldberg JD, Li X, Xie MW, et al. Focal Irradiation and Systemic Tgfbeta Blockade in Metastatic Breast Cancer. Clin Cancer Res (2018) 24(11):2493-504. doi: 10.1158/1078-0432.CCR-17-3322

133. Formenti SC, Hawtin RE, Dixit N, Evensen E, Lee P, Goldberg JD, et al. Baseline T Cell Dysfunction by Single Cell Network Profiling in Metastatic Breast Cancer Patients. J Immunother Cancer (2019) 7(1):177. doi: 10.1186/ s40425-019-0633-x

134. Rama N, Saha T, Shukla S, Goda C, Milewski D, Mascia AE, et al. Improved Tumor Control Through T-Cell Infiltration Modulated by Ultra-High Dose Rate Proton FLASH Using a Clinical Pencil Beam Scanning Proton System. Int J Radiat Oncol Biol Phys (2019) 105(1):S164-5. doi: 10.1016/j. ijrobp.2019.06.187

135. Montay-Gruel P, Acharya MM, Goncalves Jorge P, Petit B, Petridis IG, Fuchs $\mathrm{P}$, et al. Hypofractionated FLASH-RT as an Effective Treatment Against Glioblastoma That Reduces Neurocognitive Side Effects in Mice. Clin Cancer Res (2021) 27(3):775-84. doi: 10.1158/1078-0432.CCR-20-0894

Conflict of Interest: The authors declare that the research was conducted in the absence of any commercial or financial relationships that could be construed as a potential conflict of interest.

Copyright (c) 2021 De Martino, Padilla, Daviaud, Wu, Gartrell and Vanpouille-Box. This is an open-access article distributed under the terms of the Creative Commons Attribution License (CC BY). The use, distribution or reproduction in other forums is permitted, provided the original author(s) and the copyright owner(s) are credited and that the original publication in this journal is cited, in accordance with accepted academic practice. No use, distribution or reproduction is permitted which does not comply with these terms. 